\title{
Trend in Antimicrobial Resistance of Staphylococcus aureus: Results from the China Antimicrobial Surveillance Network (CHINET) in the Last I5-Year- Period Reports (2005-20 I9) [Retraction]
}

\author{
Liang Y, Qiu L, Zheng X, Liu J. Infect Drug Resist. \\ 2021;14:2179-2181.
}

At the request of the authors, the Editor and Publisher of Infection and Drug Resistance wish to retract the published article. The data reported in the article was acquired from the China Antimicrobial Surveillance Network (CHINET) (http:// www.chinets.com). CHINET prohibits the unauthorized publication of its data and the authors have advised they did not obtain the required permission to publish the data reported.
The authors wish to apologise for this error.

Our decision-making was informed by our policy on publishing ethics and integrity and the COPE guidelines on retraction.

The retracted article will remain online to maintain the scholarly record, but it will be digitally watermarked on each page as "Retracted".

\section{Publish your work in this journal}

Infection and Drug Resistance is an international, peer-reviewed openaccess journal that focuses on the optimal treatment of infection (bacterial, fungal and viral) and the development and institution of preventive strategies to minimize the development and spread of resistance. The journal is specifically concerned with the epidemiology of antibiotic resistance and the mechanisms of resistance development and diffusion in both hospitals and the community. The manuscript management system is completely online and includes a very quick and fair peerreview system, which is all easy to use. Visit http://www.dovepress.com/ testimonials.php to read real quotes from published authors. 